\title{
THE IMPORTANCE OF TEACHING TITRATION CURVES IN ANALYTICAL CHEMISTRY
}

\author{
FERNANDEZ-MAESTRE, Roberto \\ Universidad de Cartagena, Programa de Química, Campus de San Pablo, Cartagena, Colombia. \\ e-mail:rfernandezm@unicartagena.edu.co
}

Received 09 December 2019; received in revised form 17 January 2020; accepted 05 March 2020

\section{RESUMO}

As curvas de titulação são um assunto importante de um curso de Química Analítica. O principal objetivo do cálculo das curvas de titulação é a seleção de um indicador para essas titulações. O cálculo dos erros de titulação é imperativo porque eles estabelecem se um determinado indicador pode ser usado para uma determinada titulação. Este estudo revisa a literatura disponível sobre curvas de titulação e calcula seus erros. Seu objetivo é chamar a atenção para a importância de que os estudantes de graduação em química terem competências para determinar os erros de titulação, em vez de competências para criar curvas de titulação, pois o objetivo final dessas curvas é determinar o erro cometido ao usar um determinado indicador para determinar seus pontos finais. Este estudo mostra que o cálculo do $\mathrm{pH}$ e do potencial no ponto de equivalência nas titulações ácido-base e redox, respectivamente, não é necessário para escolher o indicador de titulação, que gera um erro aceitável de acordo com o tipo de aplicação. São apresentados métodos para calcular esses erros nos quatro principais tipos de titulações; aqueles para titulações complexométricas e de precipitação são mais simples que os da literatura. Aqui, também é demonstrado que cálculo dos pontos imediatamente após e antes da inflexão da curva são mais importantes para esta seleção nesses dois tipos de titulações. Além disso, é mostrado que as curvas complexométricas e de precipitação não são necessárias para selecionar indicadores para essas titulações. Essas demonstrações são importantes porque os professores de química analítica podem desconsiderar o ensino de tópicos significativos gastando tempo calculando curvas de titulação desnecessárias (titulações complexométricas e de precipitação) ou pontos desnecessários de curvas de titulação (titulações redox e ácido-base) quando o cálculo dos erros de titulação dessas reações é mais importante Este tópico é negligenciado pela maioria dos livros de química analítica. Os programas de graduação em química devem se concentrar mais no cálculo dos erros de titulação do que na construção de curvas de titulação.

Palavras-chave: erro de titulação; erro indicador; seleção de indicadores; erro de ponto final

\section{ABSTRACT}

Titration curves are an essential subject of an Analytical Chemistry course. The main objective of calculating titration curves is the selection of an indicator for such titrations. The calculation of titration errors is imperative because they establish if a given indicator can be used for a given titration. This study reviews the available literature on titration curves and calculating their errors. Its purpose is to draw attention to the importance of undergraduate chemistry students having competencies to determine the titration errors rather than skills to build titration curves as the ultimate purpose of these curves is to determine the failure committed when using a given indicator to assess their endpoints. It is shown that the $\mathrm{pH}$ and potential calculation at the equivalence point in acid-base and redox titrations, respectively, are not required to choose the titration indicator, one that yields an acceptable error according to the type of application needed. Methods to calculate these errors in the four main types of titrations are presented; those for complexometric and precipitation titrations are simpler than in the literature. Here, it is also demonstrated that calculating points immediately after and before the curve inflection are more critical for this selection in these two types of titrations. Also, it is deducted that complexometric and precipitation curves are not required to select indicators for these titrations. These demonstrations are essential because analytical chemistry teachers may disregard teaching important topics by spending time calculating unnecessary titration curves (complexometric and precipitation titrations) or additional points of titration curves (redox and acid-base titrations) when the calculation of titration errors of these reactions is more critical. Most analytical chemistry textbooks neglect this topic. Undergraduate chemistry programs should focus more on calculating titration errors than on the construction of titration curves.

Keywords: titration error; indicator error; indicator selection; end-point error 


\section{INTRODUCTION:}

The calculation of titration curves is a topic that demands a large portion of the time available for teaching an Analytical Chemistry course. This calculation allows a perspective of the changes in analyte or titrant along the titration, the estimation of the unknown analyte concentration, or, more importantly, the selection of an indicator for such titration. These titration curves are not entirely required or not at all to select an indicator and, in these cases, their calculation is just an academic exercise. By spending time in the calculation of these titration curves, significant subjects in Analytical Chemistry courses are ignored.

In his response to Daniel Harris about the importance of titration curves (Harris, 2008), Stephen Hawkes states that "choosing an indicator for an acid-base titration requires only calculation of the $\mathrm{pH}$ of the salt solution that is formed at the endpoint. Calculating the whole titration curve merely complicates the issue.

...Similar considerations apply to other kinds of titration" (Hawkes, 2008).

This study demonstrates that more information than this $\mathrm{pH}$ is required to choose an indicator. Also, Harris states that he has eliminated the titration curve calculations for EDTA and redox reactions in writing a lower-level analytical chemistry textbook (Harris, 2008). This elimination might complicate the selection of indicators in the case of redox reactions; however, because his is a lower-level analytical chemistry textbook, these types of titrations were not going to be considered, but only acid-base titrations. Harris also states that calculating titration curves allows the teacher to select the right indicator and to estimate the titration error in using that indicator (Harris, 2008), but this does not apply to precipitation and EDTA titrations, as demonstrated in the present study.

Better than calculating equivalence point concentrations in redox and acid-base titrations and complexometric and precipitation titration curves is the calculation of the indicator errors, subjects that many analytical chemistry textbooks skip. In this paper, it is shown that to select the right indicator of acid-base and redox titrations, the $\mathrm{pH}$ and the potential at the equivalence points are not needed but only calculating these parameters immediately after and before the curve inflection. In analytical chemistry, teachers might disregard teaching other vital subjects by committing time to the calculation of needless portions of the titration curves.

Consequently, this study aimed to highlight the significance of determining the titration errors rather than building titration curves as the main objective of them is to determine the titration error when using a given indicator.

\section{MATERIALS AND METHODS:}

This study reviews the available literature on titration curves and calculating their errors. Its purpose is to draw attention to the importance of undergraduate chemistry students having competencies to determine the titration errors rather than competencies to build titration curves as the ultimate purpose of these curves is to determine the error committed when using a given indicator to assess their endpoints.

\section{RESULTS AND DISCUSSION:}

\subsection{Acid-base and redox titrations}

Figure 1 shows the acid-base titration of $20.00 \mathrm{ml}$ of $\mathrm{HCl}$ with $\mathrm{NaOH}$ at several concentrations using phenolphthalein as an indicator. It can be seen that phenolphthalein works well for the titration of $0.100 \mathrm{~mol} \mathrm{~L}^{-1} \mathrm{HCl}$ but may introduce an indicator error as large as $0.4 \mathrm{ml}$ in the titration of $0.0100 \mathrm{~mol} \mathrm{~L}^{-1} \mathrm{HCl}$, the volume between the endpoint, $20 \mathrm{ml}$, and the dotted line (insert in Figure 1), which indicates the highest $\mathrm{pH}$ at which a regular person could visualize the endpoint at those concentrations.

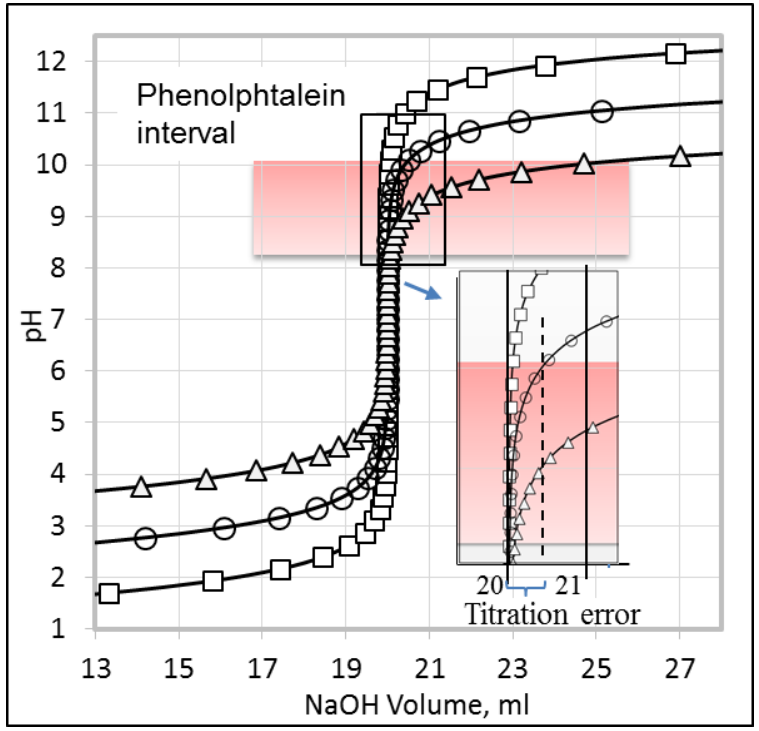

Figure 1. Acid-base titration of $20.00 \mathrm{ml}$ of 0.100 $(\square), 0.0100$ (o) and $0.00100(\Delta) \mathrm{mol} \mathrm{L}^{-1} \mathrm{HCl}$ with $0.100,0.0100$ and $0.00100 \mathrm{~mol} \mathrm{~L}^{-1} \mathrm{NaOH}$, respectively. The shaded area indicates the $\mathrm{pH}$ interval at which an average person could visualize the titration end point. In the insert, the 
volume between the dotted line and the end-point volume, $20 \mathrm{ml}$, shows the error occurring when using phenolphthalein as indicator, up to $0.4 \mathrm{ml}$ for $\mathrm{HCl} 0.0100 \mathrm{~mol} \mathrm{~L}^{-1}$ and larger for smaller concentrations (Gutz, 2010).

The titration at the lowest concentration in Figure 1, $0.00100 \mathrm{~mol} \mathrm{~L}^{-1} \mathrm{HCl}$, might yield a more significant indicator error, or might not even be visualized. Similar problems can be found using other indicators or with indicators at the beginning of the end-point inflection of acid or base titrations. Table 1 shows the $\mathrm{pK}_{\mathrm{a}}$ at which some acid-base indicators change colors. Following the same reasoning, other indicators from this table could not be used for titrations at concentrations lower than those in Figure 1. For example, cresol violet, which changes between $\mathrm{pH}$ 7.6-9.2, may introduce an indicator error of up to $\sim 1.5 \mathrm{ml}$ in the titration endpoint of $0.00100 \mathrm{~mol} \mathrm{~L}^{-1} \mathrm{HCl}$. Methyl red, which changes color between $\mathrm{pH}$ 4.2- 6.3, at the beginning of the end-point inflection, may introduce a $0.5 \mathrm{ml}$-error in the titration of 0.0100 $\mathrm{mol} \mathrm{L}^{-1} \mathrm{HCl}$ and a $\sim 3 \mathrm{ml}$-error in that of 0.00100 $\mathrm{mol} \mathrm{L}^{-1} \mathrm{HCl}$ in Figure 1. The origin of the indicator error of acid-base titration lies in the finite sensitivity of end-point indicators (Roller, 1932).

Table 1. Some acid-base indicators 5. (Skoog et al., 2015; Harris, 2007; pH meter info, 2019; Streuli, 1963)

\begin{tabular}{l|l|l}
\hline \multicolumn{1}{c|}{ Common name } & $\begin{array}{c}\text { Transition } \\
\text { Interval }\end{array}$ & $\mathbf{p K}_{\mathbf{a}}$ \\
\hline Cresol red & $0.2-1.8$ & 1.0 \\
Thymol blue & $1.2-2.8$ & 1.65 \\
Thymol blue & $8.0-9.6$ & 8.96 \\
Methyl orange & $3.1-4.4$ & 3.46 \\
Bromocresol green & $3.8-5.4$ & 4.66 \\
Ethyl orange & $3.4-4.8$ & \\
Methyl red & $4.2-6.3$ & 5.00 \\
Bromothymol violet & $5.2-6.8$ & 6.12 \\
Bromothymol blue & $6.2-7.6$ & 7.10 \\
Phenol red & $6.8-8.4$ & 7.81 \\
Cresol violet & $7.6-9.2$ & \\
Phenolphthalein & $8.3-10.0$ & 9.4 \\
Thymolphthalein & $9.3-10.5$ & \\
Alizarin yellow & $10-12$ & 11.2 \\
\hline
\end{tabular}

Equations for the calculation of titration errors in acid-base reactions have been derived (Butcher and Quintus, 1966; Gonzalez et al., 1990).

Redox titrations require similar calculations immediately after and before the curve inflection to find the right indicator. In this case, the potential calculation at the equivalence point is the hardest of all titrations for students to understand and unnecessary to select an indicator for which, again, it might be better to use the time teaching this subject in more essential topics.

For complexometric and precipitation titrations, it is not required to calculate the titration curve to select the right indicator.

\subsection{Complexometric titrations}

For a titration with EDTA, the only data required are the initial metal concentration, the $\mathrm{pH}$, the formation constant of the metal-indicator complex, and the indicator $\mathrm{K}_{\mathrm{a}}$ for the dissociation reaction between the two main species involved in the color change at the titration $\mathrm{pH}$. The calculation of the end-point metal concentration in a titration of $0.0100 \mathrm{~mol} \mathrm{~L}^{-1} \mathrm{Mg}^{2+}$ with EDTA and Eriochrome Black T (EBT) as the indicator at $\mathrm{pH} 10$ has been reported (Skoog et al., 2013) but the indicator error occurring in this titration at these conditions was not calculated. Following, there is a similar example solved for $\mathrm{Ca}^{2+}$, but the error occurring in using EBT to detect the endpoint is calculated demonstrating that EBT is not the right indicator for $\mathrm{Ca}^{2+}$ at these conditions.

Example 1. Determine the transition intervals for EBT in the titration of $25.00 \mathrm{~mL}$ of $0.0100 \mathrm{~mol} \mathrm{~L}^{-1} \mathrm{Ca}^{2+}$ with $0.0100 \mathrm{~mol} \mathrm{~L}^{-1}$ EDTA at $\mathrm{pH}$ 10. The Caln formation constant, $K_{f}$, and the second acid dissociation constant of the indicator, $K_{2}$, are:

$$
\begin{gathered}
\mathrm{Ca}^{2+}+\mathrm{In}^{3-} \leftrightarrow \mathrm{CaIn}^{-} \\
\mathrm{K}_{f}=\frac{\left[\mathrm{CaIn}^{-}\right]}{\left[\mathrm{In}^{3-}\right]\left[\mathrm{Ca}^{2+}\right]}=2.5 \times 10^{-5} \\
\mathrm{HIn}^{2-}+\mathrm{H}_{2} \mathrm{O} \leftrightarrow \mathrm{In}^{3-}+\mathrm{H}_{3} \mathrm{O}^{+} \\
\mathrm{K}_{2}=\frac{\left[\mathrm{In}^{3-}\right]\left[\mathrm{H}_{3} \mathrm{O}^{+}\right]}{\left[\mathrm{HIn}^{2-}\right]}=2.8 \times 10^{-12}
\end{gathered}
$$

Solution. Multiplying $K_{f}$ by $K_{a}$ :

$$
\begin{gathered}
K_{2} \times K_{f}=2.5 \times 10^{-5} \times 2.8 \times 10^{-12}= \\
\frac{\left[\mathrm{CaIn}^{-}\right]}{\left[\mathrm{HIn}^{2-}\right]} \frac{\left[\mathrm{H}_{3} \mathrm{O}^{+}\right]}{\left[\mathrm{Ca}^{2+}\right]}=7.0 \times 10^{-7}
\end{gathered}
$$

Solving for $\mathrm{Ca}^{2+}$ and replacing the $\mathrm{H}_{3} \mathrm{O}^{+}$ concentration at $\mathrm{pH} 10.0$ : 


$$
\left[\mathrm{Ca}^{2+}\right]=\frac{\left[\mathrm{CaIn}^{-}\right]}{\left[\mathrm{HIn}^{2-}\right]} \frac{1.0 \times 10^{-10}}{7.0 \times 10^{-7}}
$$

It can be considered that a given color in a mixture of two species with different colors can be detected by the average human eye when the concentration of the species with that color is 10 times the concentration of the species with the other color. Because Caln is red and $\mathrm{HIn}^{-2}$ is blue, the solution will be red if [Caln $] /\left[\mathrm{HIn}^{2-}\right]=10$ and blue if $\left[\mathrm{Caln} \mathrm{n}^{-}\right] /\left[\mathrm{HIn}^{2-}\right]=0.1$. Replacing these two values of [Caln- $] /\left[\mathrm{HIn}^{2-}\right]$ in Equation 1, it is found that the endpoint can be detected at a $\mathrm{Ca}^{2+}$ concentration as high as $0.0014 \mathrm{~mol} \mathrm{~L}^{-1}$ (between 0.0014 and $1.4 \times 10^{-5} \mathrm{~mol} \mathrm{~L}^{-1}$ or $\mathrm{pCa}$ values of 2.85 and 4.84). The indicator error for $0.0100 \mathrm{~mol} \mathrm{~L}^{-1}$ $\mathrm{Ca}^{2+}$ could be as high as $14 \%$ (between 0.14 and $14 \%)$ :

$$
E=100-\frac{(0.0100-0.0014)}{0.0100} \times 100=14 \%
$$

$\mathrm{A} \mathrm{Ca}^{+2}$ concentration of $0.0014 \mathrm{~mol} \mathrm{~L}^{-1}$ is obtained when adding only $21.5 \mathrm{ml}$ of the $25.0 \mathrm{ml}$ of EDTA required to reach the endpoint in this example. Figure 2 shows the transition intervals for EBT of the titration of Example 2 and the range of change of the indicator. An Excel spreadsheet In Supporting Information shows the plotting of this curve.

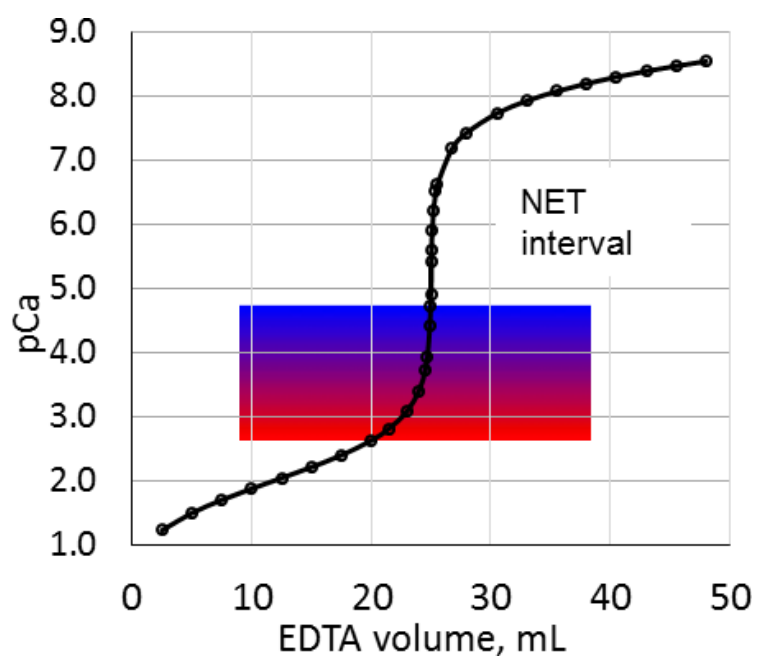

Figure 2. Color transition for EBT from red, the color of Caln, to blue, the color of $\mathrm{HIn}^{-2}$, for the titration of Example 2: $25.00 \mathrm{~mL}$ of $0.0100 \mathrm{~mol} \mathrm{~L}^{-1}$ $\mathrm{Ca}^{2+}$ with $0.0100 \mathrm{~mol} \mathrm{~L}^{-1}$ EDTA at $\mathrm{pH} 10$. The limits of the colored area correspond to $\mathrm{Ca}^{2+}$ concentrations of $0.0014 \mathrm{~mol} \mathrm{~L}^{-1}$ (below) and $1.4 \times 10^{-5} \mathrm{~mol} \mathrm{~L}^{-1}$ (above), or pCa values of 2.85 and 4.84 , the range where the average person can detect the EBT color change. The color change can be perceived $3.5 \mathrm{ml}$ before the endpoint introducing an indicator error of up to $14 \%$

Therefore, EBT is not the right indicator for $0.0100 \mathrm{~mol} \mathrm{~L}^{-1} \mathrm{Ca}^{2+}$, and it is not necessary to calculate the titration curve to find the right indicator in complexometric titrations of this type because the only data used in the preceding example were only those annotated above: initial $\mathrm{Ca}^{2+}$ concentration, titration $\mathrm{pH}, \mathrm{K}_{\mathrm{f}}$ and $\mathrm{K}_{\mathrm{a}}$. For $\mathrm{Mg}^{2+}$, in contrast, the same procedure in the same conditions yields a maximum indicator error of 0.36\%. Skoog, et al., 2013 (Figure 17.10) also shows the transition intervals for EBT in the titration of $50.00 \mathrm{ml}$ of $\mathrm{Ca}^{2+}$ and $\mathrm{Mg}^{2+}$ with EDTA and the $14 \%$ indicator error calculated in Example 1 can be visualized. Again, it can be seen from this figure that EBT is not suitable for the titration of $\mathrm{Ca}^{2+}$ but it is right for that of $\mathrm{Mg}^{2+}$.

\subsection{Precipitation titrations}

In the case of precipitation titrations, the endpoint can be determined by the Mohr, Volhard, and Fajans methods. These methods use sodium dichromate, iron and adsorption indicators such as dichlorofluorescein as the end-point indicators, respectively (Christian, 2004). None of them require the calculation of the titration curve. More important than this calculation is calculating the indicator error at the endpoint for a particular precipitation titration. This calculation is not given in conventional textbooks of analytical chemistry in precipitation or complexometric titrations (Skoog et al., 2015; Harris, 2007; Christian, 2004; Skoog et al., 2013; Harvey, 2000; Fifield and Kealey, 2000).

\subsubsection{Mohr Method}

In this method, to determine halides titrating with $\mathrm{Ag}^{+}, \mathrm{K}_{2} \mathrm{CrO}_{4}$, or other soluble chromate salt is added to the analyte solution; the formation of a reddish-brown $\mathrm{Ag}_{2} \mathrm{CrO}_{4}$ precipitate determines the endpoint.

Example 2. Determine the indicator error in the titration of $10.0 \mathrm{~mL}$ of $0.100 \mathrm{~mol} \mathrm{~L}^{-1} \mathrm{Cl}^{-}$solution with $0.100 \mathrm{~mol} \mathrm{~L}^{-1}$ silver nitrate by the Mohr method.

Solution. The silver nitrate concentration at the endpoint is: 


$$
\begin{aligned}
{\left[\mathrm{Ag}^{+}\right]=\sqrt{K s p} } & =\sqrt{1.82 \times 10^{-10}} \\
& =1.35 \times 10^{-5} \frac{\mathrm{mol}}{\mathrm{L}}
\end{aligned}
$$

The $\mathrm{K}_{2} \mathrm{CrO}_{4}$ concentration required to precipitate $\mathrm{Ag}_{2} \mathrm{CrO}_{4}$ at the endpoint is:

$$
\begin{gathered}
{\left[\mathrm{CrO}_{4}^{2-}\right]=\frac{K s p}{\left[\mathrm{Ag}^{+}\right]^{2}}=\frac{1.2 \times 10^{-12}}{1.35 \times 10^{-5}}} \\
=6.6 \times 10^{-3} \frac{\mathrm{mol}}{\mathrm{L}}
\end{gathered}
$$

But $\mathrm{K}_{2} \mathrm{CrO}_{4}$ must be more diluted $\left(\sim 10^{-6}\right.$ mol L-1) than $6.6 \times 10^{-3} \mathrm{~mol} \mathrm{~L}^{-1}$ because this concentration turns yellow the analyte solution, concealing the endpoint. This systematic error is corrected, analyzing a blank to determine the volume of titrant required to show the indicator's color. The blank consists of a small amount of chloride-free calcium carbonate, to replicate the white $\mathrm{AgCl}$ precipitate, and the indicator (Harvey, 2000). This $\mathrm{K}_{2} \mathrm{CrO}_{4}$ concentration, $\left(\sim 10^{-6} \mathrm{~mol} \mathrm{~L}^{-1}\right)$, requires silver and chloride concentrations at the endpoint of:

$$
\begin{aligned}
{\left[\mathrm{Ag}^{+}\right] } & =\sqrt{\frac{\mathrm{Ksp}}{\left[\mathrm{CrO}_{4}^{2-}\right]}}=\sqrt{\frac{1.2 \times 10^{-12}}{1 \times 10^{-6}}} \\
& =1.1 \times 10^{-3} \frac{\mathrm{md}}{\mathrm{L}}(\text { eq. } 4) \\
{\left[\mathrm{Cl}^{-}\right] } & =\frac{K s p}{\left[\mathrm{Ag}^{+}\right]}=\frac{1.82 \times 10^{-10}}{1.1 \times 10^{-3}} \\
& \left.=1.6 \times 10^{-7} \frac{\mathrm{md}}{L} \quad \text { eq. } 5\right)
\end{aligned}
$$

This chloride concentration would decrease the indicator error when compared to the initial chloride concentration, $0.100 \mathrm{~mol} \mathrm{~L}^{-1}$ because most of the original chloride has precipitated. However, to reach a silver concentration of $1.1 \times 10^{-3} \mathrm{~mol} \mathrm{~L}^{-1}$, the endpoint must be passed, adding an excess of silver, producing an indicator error. Two ways can be used to determine if the Mohr method is adequate to detect the endpoint in Example 2.

MOHR-ERROR, METHOD 1. To reach a silver concentration of $1.1 \times 10^{-3} \mathrm{~mol} \mathrm{~L}^{-1}$, the concentration required at the endpoint to precipitate $\mathrm{Ag}_{2} \mathrm{CrO}_{4}$, with a $\sim 10^{-6} \mathrm{~mol} \mathrm{~L}^{-1} \mathrm{~K}_{2} \mathrm{CrO}_{4}$ concentration in $21.0 \mathrm{ml}$ (total volume at the endpoint, including $1 \mathrm{ml}$ of indicator solution), an excess of $\sim\left(1.1 \times 10^{-3} \mathrm{~mol} \mathrm{~L}^{-1} 1.35 \times 10^{-5} \mathrm{~mol} \mathrm{~L}\right.$ $\left.{ }^{1}\right) \times 0.0200 \mathrm{~L}=2.3 \times 10^{-5} \mathrm{~mol}$ of silver must be added.
This amount of silver corresponds to a volume of $\mathrm{V}=\mathrm{n} \mathrm{M}^{-1}=2.3 \times 10^{-5} \mathrm{~mol} \mathrm{Ag}^{+} / 0.100 \mathrm{~mol} \mathrm{~L}^{-1} \mathrm{Ag}^{+} \cong$ $0.23 \mathrm{~mL}$ of titrant. This volume corresponds to a $2.3 \%$ error for the $10.0 \mathrm{ml}$ calculated to reach the endpoint and does not depend on the volume at the endpoint. This error increases with decreasing reagent concentrations, e.g., to $23 \%$ when 0.0100 mol L-1 $\mathrm{Cl}^{-}$is titrated with $0.0100 \mathrm{~mol} \mathrm{~L}^{-1}$ silver nitrate. Therefore, the final formula to calculate the indicator error in the Mohr method is:

$$
\text { Error }=\frac{\left(1.1 \times 10^{-3}-\sqrt{K_{a} p_{a}}\right) V_{T}}{\left(V_{A g+}\right)\left[\mathrm{Ag}^{+}\right]}
$$

Where $1.1 \times 10^{-3}$ is the concentration of $\mathrm{Ag}^{+}$ at the endpoint using $1 \times 10^{-6} \mathrm{~mol} \mathrm{~L}^{-1}$ of $\mathrm{K}_{2} \mathrm{CrO}_{4}$ as the indicator; $K s p_{a}$ the solubility product of the analyte salt that precipitates (for 1:1 salts); $\sqrt{K s p_{a}}$ the concentration of $\mathrm{Ag}^{+}$at the endpoint without using indicator (for $1: 1$ salts); $V_{T}$ the total volume at the endpoint, the added volumes of analyte and silver nitrate; $V_{A g}+$ the volume of $\mathrm{Ag}^{+}$ to reach the endpoint; and $\left[\mathrm{Ag}^{+}\right]$the concentration of $\mathrm{Ag}^{+}$titrant.

MOHR-ERROR, METHOD 2. Here, the most significant indicator error that can be accepted is specified; let say $1 \%$. Then, the approximate limits of the end-point inflection are calculated in terms of silver concentration, to obtain the $1 \%$ indicator error. In the titration of 10.0 $\mathrm{mL}$ of $0.100 \mathrm{~mol} \mathrm{~L}^{-1} \mathrm{Cl}^{-}$solution with $0.100 \mathrm{~mol} \mathrm{~L}^{-1}$ silver nitrate, these limits are $0.1 \mathrm{ml}$ after and before the equivalence point where the indicator error is $(0.1 \mathrm{ml} / 10 \mathrm{ml}) \times 100 \leq 1 \%$. The silver concentrations $0.1 \mathrm{ml}$ after and before the equivalence point of this titration are $5.0 \times 10^{-4} \mathrm{~mol}$ $\mathrm{L}^{-1}$ and $3.62 \times 10^{-7} \mathrm{~mol} \mathrm{~L}^{-1}$, respectively. If the silver concentration at the endpoint found using the chromate indicator, $1.1 \times 10^{-3} \mathrm{~mol} \mathrm{~L}^{-1}$ (Equation 4), is within this concentration range, then the indicator can be used with an error $\leq 1 \%$. In this case, the indicator should not be used because $1.1 \times 10^{-3} \mathrm{~mol} \mathrm{~L}^{-1}$, calculated above, is not within the said concentration range.

Equations for the calculation of titration errors in precipitation reactions using the Mohr method have been derived (Belcher et al., 1957).

\subsubsection{Volhard Method}

In the Volhard method, the analyte is added with an excess of standard $\mathrm{Ag}^{+}$, which is titrated with standard $\mathrm{SCN}^{-}$in a strongly acidic solution in the presence of $\mathrm{Fe}^{3+}$. At the endpoint, a reddish complex, $\mathrm{Fe}(\mathrm{SCN})^{2+}$, is formed. The 
does not require the calculation of the titration curve (Harvey, 2000). Again, this error neither depends on the volume at the endpoint nor the $K s p$ of the analyte-titrant salt nor the analyte-titrant precipitation reaction.

Example 3. Calculate the concentration of $\mathrm{Fe}^{3+}$ required to produce a $\sim$ zero indicator error in the following titration: $15.00 \mathrm{ml}$ of $0.100 \mathrm{~mol} \mathrm{~L}^{-1} \mathrm{Cl}^{-}$ are added with $30.00 \mathrm{ml}$ of $0.100 \mathrm{~mol} \mathrm{~L}^{-1} \mathrm{Ag}^{+}$; the $15.0 \mathrm{ml}$ excess of $0.100 \mathrm{~mol} \mathrm{~L}^{-1} \mathrm{Ag}^{+}$is back-titrated with $15.00 \mathrm{ml}$ of $0.100 \mathrm{~mol} \mathrm{~L}^{-1} \mathrm{KSCN}$.

Solution. At the back-titration end point:

$$
\left[\mathrm{Ag}^{+}\right]=[S C N]
$$

If $\mathrm{Fe}^{3+}$ is used as the indicator, part of the $\mathrm{SCN}^{-}$will be present as $\mathrm{Fe}(\mathrm{SCN})^{2+}$ at the endpoint and, therefore:

$$
\left[\mathrm{Ag}^{+}\right]=\left[S C N^{-}\right]+\left[\mathrm{Fe}(\mathrm{SCN})^{2+}\right]
$$

Replacing in the solubility product expression $K s p=\left[\mathrm{Ag}^{+}\right][\mathrm{SCN}]$ :

$$
\begin{gathered}
{\left[\mathrm{Ag}^{+}\right]=\frac{K s p}{\left[S C N^{-}\right]}=\frac{1.1 \times 10^{-12}}{\left[S C N^{-}\right]}} \\
=\left[S C N^{-}\right]+\left[\mathrm{Fe}(S C N)^{2+}\right]
\end{gathered}
$$

Replacing the $\mathrm{Fe}(\mathrm{SCN})^{2+}$ concentration required to detect the endpoint, $6.4 \times 10^{-6} \mathrm{~mol} \mathrm{~L}^{-1}$, and solving for $\mathrm{SCN}^{-}$in the last two terms:

$$
\begin{gathered}
{\left[S C N^{-}\right]^{2}+6.4 \times 10^{-6}\left[S C N^{-}\right]-1.1 \times 10^{-12}=0} \\
{\left[S C N^{-}\right]=1.7 \times 10^{-7} \mathrm{~mol} \mathrm{~L}^{-1}}
\end{gathered}
$$

This concentration yields a small indicator error: the $\mathrm{SCN}^{-}$concentration at the endpoint without using indicator is $(K s p)^{1 / 2}=\left(1.1 \times 10^{-12}\right)^{1 / 2}=$ $1.04 \times 10^{-6} \mathrm{~mol} \mathrm{~L}^{-1}$. The difference in mmoles between this concentration and the one calculated above, using the indicator, $1.7 \times 10^{-7}$, is $\left(1.04 \times 10^{-6}\right.$ $\left.1.7 \times 10^{-7}\right) \mathrm{mmol} \mathrm{mL}^{-1} \times 60 \mathrm{~mL}=5.2 \times 10^{-5} \mathrm{mmol}$ of $\mathrm{SCN}^{-}$, which requires only $5.2 \times 10^{-5} \mathrm{mmol} \mathrm{SCN}^{-}$ $/\left(0.100 \mathrm{mmol} \mathrm{SCN}^{-} \mathrm{ml}^{-1}\right)=5.2 \times 10^{-4} \mathrm{ml}^{-}$of SCN titrant. This volume corresponds to an indicator error of $\left[5.2 \times 10^{-4} \mathrm{ml}\right.$ of $\mathrm{KSCN} / 15.00 \mathrm{ml}$ of KSCN] $\mathrm{x}$ $100=0.0035 \%$. Then, $\left[\mathrm{SCN}^{-}\right]$is replaced by $1.7 \times 10^{-7} \mathrm{~mol} \mathrm{~L}^{-1}$ and $\left[\mathrm{Fe}(\mathrm{SCN})^{2+}\right]$ by $6.4 \times 10^{-6} \mathrm{~mol}$ $\mathrm{L}^{-1}$ in the formation constant expression of $\mathrm{Fe}(\mathrm{SCN})^{2+}$ to obtain the $\mathrm{Fe}^{3+}$ concentration required to visualize the endpoint:

$$
\begin{gathered}
K_{f}=\frac{\left[\mathrm{Fe}(\mathrm{SCN})^{2+}\right]}{\left[\mathrm{Fe}^{3+}\right]\left[S C N^{-}\right]}=\frac{6.4 \times 10^{-6}}{\left[\mathrm{Fe}^{3+}\right] \times 1.7 \times 10^{-7}} \\
=1.05 \times 10^{3}
\end{gathered}
$$

Solving for $\mathrm{Fe}^{3+}$, a value of $0.036 \mathrm{~mol} \mathrm{~L}^{-1}$ is obtained. If the $\mathrm{Fe}^{3+}$ concentration is kept between 0.02 and $1.6 \mathrm{~mol} \mathrm{~L}^{-1}$ an indicator error $\leq 0.1 \%$ is obtained. ${ }^{13}$ Therefore, the final formula to calculate the indicator error in the Volhard method, similar to the one derived above for the Mohr method, is:

$$
\begin{aligned}
& \text { Error }=\frac{\left(1.04 \times 10^{-6}-\frac{\left.6.4 \times 10_{3+}^{-6}\right)}{\left.1.05 \times 10^{-6}{ }^{2}\right]} V_{T}\right.}{\left(V_{S C N^{-}}\right)\left[S C N^{-}\right]}
\end{aligned}
$$

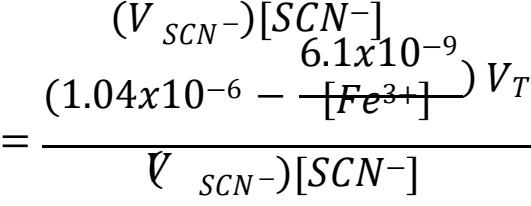

Where $1.04 \times 10^{-6}$ is the $\mathrm{SCN}^{-}$concentration at the equivalence point of the back-titration without the addition of $\mathrm{Fe}^{3+} ; 6.4 \times 10^{-6}$ the $\mathrm{Fe}(\mathrm{SCN})^{2+}$ concentration required to detect the endpoint; $1.05 \times 10^{3}$ the $\mathrm{Fe}(\mathrm{SCN})^{2+}$ formation

constant; $V_{T}$ the total volume at the back-titration endpoint, the added volumes of analyte, silver nitrate and $\mathrm{SCN}^{-}$; $V_{S_{S N}}$ the volume of $\mathrm{SCN}^{-}$to reach the back-titration endpoint; and [SCN-] the concentration of the KSCN back-titrant. This formula is similar to that derived for the Mohr method because the terms of the subtraction, in parenthesis, are the $\mathrm{SCN}^{-}$concentration at the equivalence point of the back-titration without the addition of indicator and adding it, respectively. In Supporting Information, a spreadsheet shows the calculation of this concentration and the indicator error associated.

\subsubsection{Fajans Method}

In the Fajans method, an adsorption indicator changes color when adsorbed onto the precipitate. For example, when titrating $\mathrm{Cl}^{-}$with $\mathrm{Ag}^{+}$, the anionic dye dichlorofluorescein is used as the indicator. Before the endpoint, the $\mathrm{AgCl}$ precipitate has a negative surface charge due to the adsorption of excess $\mathrm{Cl}^{-}$. The anionic indicator is repelled by the precipitate and remains in solution where it has a green-yellowish color. After the endpoint, the precipitate has a positive surface charge due to the adsorption of excess $\mathrm{Ag}^{+}$. The anionic indicator now adsorbs onto the precipitate's surface where its color is pink, signaling the endpoint (Harvey, 2000). The indicator error in this method is small and is related to the amount of $\mathrm{Ag}^{+}$in excess required to turn the 
precipitate surface charge to positive to allow the adsorption of enough dichlorofluorescein to become the solution greenish-pinkish.

\section{CONCLUSIONS:}

In a regular analytical course, the teacher must consider teaching the calculation of the titration curve in complexometric and precipitation experiments because it is not required to choose the chemical indicator. For redox and acid-base titrations, at least, the points $0.1 \mathrm{ml}$ before and after the equivalence point must be calculated to select the chemical indicator. In argentometric experiments using the Mohr method, the lowest concentrations to be used for the titrant and analyte are $0.1 \mathrm{M}$ to avoid indicator errors more significant than $2.2 \%$. Ways to calculate indicator errors in complexometric and precipitation titrations are presented that are simpler than those in the literature (Butcher and Quintus, 1966; Gonzalez, G. G.: Jimenez, et al., 1990; Belcher et al., 1957; Butler, 1963).

\section{REFERENCES:}

1. Harris, D. C. J. Chem. Ed. 2008, 82, 498

2. Hawkes, S. J. J. Chem. Ed. 2008, 82, 499.

3. Roller, P. S. J. Am. Chem. Soc. 1932, 54, 3485.

4. Butcher, J., Quintus, F. J. Chem. Ed. 1966, 43, 546.

5. Gonzalez, G. G.: Jimenez, A. M.: Asuero, A. G. Microchem. J. 1990, 41, 113.

6. Skoog, D. A., West D. M., Holler F. J., Crouch, S. R. Fundamentals of Analytical Chemistry, $9^{\text {th }}$ ed., Cengage Learning: Mexico, 2015.

7. Harris, D. Quantitative Chemical Analysis, $7^{\text {th }}$ ed., Freeman: New York, 2007.

8. http://www.ph-meter.info/pH-measurementsindicators, accessed August 2019.

9. Streuli, C. A. In Handbook of Analytical Chemistry; Meites L., ed., McGraw-Hill: New York, 1963, pp. 3-35 and 3-36

10. Gutz, I. G. R. Curtipot pH Calculator + Acid-

Base Titration.

http://www.iq.usp.br/gutz/Curtipot.html;

Universidade de São Paulo, Brazil, 2010

11. Christian, G. Analytical Chemistry, $6^{\text {th }}$ ed., Wiley: New York, 2004.

12. Skoog, D. A., West D. M., Holler F. J., Crouch, S. R. Fundamentals of Analytical Chemistry, $8^{\text {th }}$ ed., Thomson: Mexico, 2013.

13. Harvey, D. Modern Analytical Chemistry, International Edition, McGraw-Hill: Boston, 2000.

14. Fifield, F. W., Kealey, D. Principles and Practice of Analytical Chemistry, $5^{\text {th }}$ ed., Blackwell Science: Cambridge, 2000.

15. Belcher, R., Macdonald, A. M. G., Parry, E. Anal. Chim. Acta. 1957, 16, 524.

16. Butler, J. N. J. Chem. Ed. 1963, 40, 66. 